PiJIES: Pedagogik Journal of Islamic Elementary School April 2018, Vol.1, No.1, hal. 81-90

ISSN(P): 2356-1483; ISSN(E): 2615-3904

(c)2018 PGMI IAIN Palopo. http:// ejournal-iainpalopo.ac.id/ PiJIES

\title{
PENINGKATAN MOTIVASI DAN HASIL BELAJAR IPA MELALUI PENERAPAN MODEL SCRAMBLE
}

\author{
Nur Azizah Zainudin \\ Institut Agama Islam Negeri Palopo \\ Jl. Agatis Balandai Kota Palopo, 91914 \\ E-mail: ichaazizah44@yahoo.com
}

\begin{abstract}
This study aims to improve the motivation and learning outcomes of science students of class IIIb SDN 24 Temmalebba by applying a model of scramble learning on the material classification of plants based on the seeds. This research is PTK, designed through three cycles. Subjects were 39 students. Data collection techniques are observation, documentation, interviews, and tests. The research data obtained were analyzed using descriptive statistical formula to express descriptively the research result. Furthermore, to explain the results of descriptive quantitative research, used reduction analysis techniques, presentation, and conclusions. From the results of the study found that in the pre cycle, the percentage of student motivation $47.86 \%$ with the average value of students is 60 , classical completeness $51.28 \%$. After applying the scramble model, the first cycle of student motivation percentage is $62,67 \%$, student average 70,1, 62,58\% classical mastery. Furthermore, cycle II percentage of student motivation $68,10 \%$ with average value of student is 85,38 , classical mastery $82,35 \%$. Then, in the third cycle, the percentage of students' motivation reaches $78.43 \%$, the average score of students is $88.94,100 \%$ classical mastery. Thus, the motivation and learning outcomes of science in class III SDN Temmalebba by applying the scramble model performed on the I-III cycle showed an increase.
\end{abstract}

Keywords: Learning Motivation, Scramble Model, and Science Learning Outcomes.

\begin{abstract}
Abstrak
Penelitian ini bertujuan meningkatkan motivasi dan hasil belajar IPA siswa kelas IIIb SDN 24 Temmalebba dengan menerapkan model pembelajaran scramble pada materi penggolongan tumbuhan berdasarkan bijinya. Penelitian ini adalah PTK, didesain melalui tiga siklus. Subjek penelitian berjumlah 39 siswa. Teknik pengumpulan data yaitu observasi, dokumentasi, wawancara, dan tes. Data penelitian yang diperoleh dinalisis menggunakan rumus statistik deskriptif untuk mengungkapkan secara deskriptif hasil penelitian. Selanjutnya, untuk menjelaskan hasil penelitian yang bersifat kuantitatif deskriptif, digunakan teknik analisis reduksi, penyajian, dan penarikan kesimpulan. Dari hasil penelitian ditemukan bahwa pada prasiklus, persentasi motivasi siswa $47,86 \%$ dengan nilai rata-rata siswa adalah 60 , ketuntasan klasikal $51,28 \%$. Setelah menerapkan model scramble, siklus I persentasi motivasi siswa $62,67 \%$, nilai rata-rata siswa 70,1, ketuntasan klasikal 62,58\%. Selanjutnya, siklus II persentasi motivasi siswa $68,10 \%$ dengan nilai rata-rata siswa adalah 85,38 , ketuntasan klasikal 82,35\%. Kemudian, pada siklus III persentasi motivasi siswa mencapai 78,43\%, nilai rata-rata siswa adalah 88,94, ketuntasan klasikal 100\%. Dengan demikian, motivasi dan hasil pembelajaran IPA di kelas IIIb SDN Temmalebba dengan menerapkan model scramble yang dilakukan pada siklus I-III menunjukkan peningkatan.
\end{abstract}

Kata Kunci,: Motivasi Belajar, Model Scramble, dan Hasil Belajar IPA. 


\section{2 | Nur Azizah Zainuddin \\ PENDAHULUAN}

Mata pelajaran IPA bagi sebagian siswa dikenal sebagai mata pelajaran yang ditakuti dan tidak disukai siswa. Kecenderungan ini biasanya berawal dari pengalaman belajar meraka yang memberikan kesan bahwa pelajaran IPA adalah pelajaran berat. Ilmu Pengetahuan Alam (IPA) dapat didefinisikan sebagai suatu pemberian kemampuan menguasai pengetahuan dan fakta tentang alam. Misalnya, manusia, hewan, dan tumbuhan, meliputi daur hidup, ekosistem dan lain sebagainya. Ahmad Sutanto ( 2014:167 ) mengungkapkan bahwa IPA adalah usaha memahami alam semesta melalui observasi menggunakan prosedur tertentu dan dijelaskan menggunakan nalar sehingga mendapat suatu kesimpulan. IPA merupakan cara mencari tahu tentang alam untuk menguasai pengetahuan agar siswa memiliki sikap ilmiah seperti rasa ingin tahu, dan sebagainya. Perspektif siswa tersimpan dalam pikiran mereka bahwa pelajaran IPA adalah pelajaran yang berat. Sehingga siswa kurang termotivasi dalam mengikuti pelajaran IPA.

Hal tersebut sesuai dengan hasil observasi disekolah pada saat pembelajaran IPA berlangsung. Siswa cenderung kurang aktif dalam menyampaikan ide dan tidak antusias mengikuti pelajaran. Hal ini dirasa perlu disikapi dengan meningkatkan motivasi siswa pada saat pembelajaran berlangsung. Istilah motivasi berasal dari kata motif yang diartikan sebagai kekuatan yang terdapat dalam individu, yang menyebabkan individu tersebut berbuat. Motif dapat berkembang dari dalam diri individu akibat adanya rangsangan atau stimulus. Hamzah (2007:23) mengungkapkan bahwa motivasi dan belajar merupakan dua hal yang saling memengaruhi. Motivasi adalah dorongan dasar yang menggerakkan seseorang berbuat. Belajar adalah perubahan tingkah laku secara relatif permanen dan terjadi bertujuan untuk mencapai tujuan tertentu.

Motivasi dapat didefinisikan sebagai suatu pendorong melakukan sebuah tindakan, mencapai tujuan, atau keadaan dan kesiapan individu yang mendorongnya untuk berbuat sesuatu dalam mencapai tujuan. Sesuai dengan pendapat Mc. Donald (dalam Sardiman, 2003) motivasi adalah perubahan energi individu meliputi munculnya "feeling" dan didahului dengan tanggapan terhadap adanya tujuan. Menurut Suprijono (2013) motivasi belajar berkaitan erat dengan tujuan belajar. Oleh sebab itu dipahami bahwa motivasi mempunyai fungsi (1) Mendorong siswa untuk berbuat. (2) Menentukan arah kegiatan pembelajaran yakni ke arah tujuan belajar yang hendak dicapai. (3) Menyeleksi kegiatan pembelajaran.

Guru dalam hal ini diharapkan tidak monoton dalam menyajikan materi ajar kepada siswa, agar siswa dapat memiliki motivasi dalam mengikuti pelajaran. Untuk meningkatkan motivasi belajar siswa, guru memilih model 
dan media yang dianggap sesuai dengan mata pelajaran IPA untuk mewujudkan kondisi belajar yang kondusif dan menyenangkan. Syaiful Sagala (2007:63) menjelaskan bahwa pembelajaran memiliki dua karakteristik yaitu (1) melibatkan mental siswa secara maksimal, menghendaki aktivitas siswa dalam proses berpikir bukan hanya menuntut siswa untuk mendengar; (2) membangun suasana yang memungkinkan siswa untuk berdialog dan proses tanya jawab terus menerus diarahkan untuk memperbaiki dan meningkatkan kemampuan berpikir siswa, agar kemampuan berpikir tersebut dapat membantu siswa mendapatkan pengetahuan yang mereka bangun sendiri. Dalam hal ini, model scramble dianggap mampu mengaktifkan siswa dalam pembelajaran IPA agar hasil belajar siswa pun menunjukkan peningkatan.

Model pembelajaran merupakan faktor penting yang dapat membantu guru dalam mengoptimalkan pembelajaran di kelas. Model pembelajaran adalah pola atau bentuk yang digunakan sebagai pedoman dalam merencanakan pembelajaran dalam kelas (Suprijono, 2012:46). Model pembelajaran yang diterapkan dalam penelitian ini yaitu model pembelajaran kooperatif. Model pembelajaran kooperatif dapat menumbuhkan pembelajaran efektif yaitu pembelajaran yang memudahkan siswa belajar sesuatu yang bermanfaat seperti, fakta, keterampilan, nilai, dan konsep. (Suprijono, 2012:58).

Scramble dalam hal ini adalah model yang sekaligus menggunakan media yang dipersiapkan oleh guru berbentuk kartu soal dan kartu jawaban yang telah diacak oleh guru untuk dipecahkan. Menurut Suyatno dalam Iryanti (2012:2) bahwa model pembelajaran scramble adalah suatu metode belajar yang menggunakan kartu yaitu soal dan jawaban yang dipasangkan atau diurutkan menjadi urutan yang sempurna. Sehingga siswa dituntut untuk mampu berpikir kreatif dalam pembelajaran di dalam kelas, untuk dapat mengurutkan kata-kata dalam kunci jawaban. Sedangkan menurut Robert B. Taylor dalam Miftahul Huda (2015: 505) model scramble merupakan salah satu model pembelajaran yang dapat meningkatkan konsentrasi dan kemampuan berpikir siswa. Metode ini mengharuskan siswa menyinergikan otak kanan dan otak kiri. Berdasarkan uraian tersebut dipahami bahwa model scramble mampu meningkatkan konsentrasi siswa dengan mengaktifkan nalar dan keterampilan berpikir siswa dalam pembelajaran. Sedangkan menurut Hanafiah dan Suhana dalam Nur (2011:18) model pembelajaran scramble menuntut siswa aktif bekerja sama dan bertanggung jawab terhadap kelompoknya untuk menyelesaikan soal acak guna memperoleh poin dan meningkatkan kebersamaan siswa. Model pembelajaran tersebut mengharuskan siswa untuk berperan aktif dalam 


\section{4 | Nur Azizah Zainuddin}

pembelajaran dan mengoptimalkan kemampuan berpikir cepat siswa dengan penuh tanggung jawab untuk meningkatkan kebersamaan siswa.

Menurut Suyatno dalam Iis (2011:13) tahapan pembelajaran scramble adalah sebagai berikut. (1) membuat kartu soal sesuai materi yang kan diajarkan. (2) membuat kartu jawaban yang diacak. (3) guru membuat pilihan jawaban yang diacak. (4) guru menyajikan materi ajar kepada siswa. (5) guru membagikan kartu soal dan kartu jawaban pada kelompok. (6) siswa berkelompok mengerjakan kartu soal. (7) siswa berkelompok dan saling membantu mengerjakan soal pada kartu soal. (8) siswa mencari jawaban untuk setiap soal. (9) siswa mencari jawaban yang cocok untuk setiap soal yang mereka kerjakan dan memasangkannya pada kartu soal. Berdasarkan pengertian dan langkah-langkah penerapan model tersebut, model pembelajaran scramble dilandasi oleh teori belajar konstruktivisme yaitu siswa harus menemukan sendiri dan menjelaskan informasi kompleks. Menutut teori ini, suatu prinsip yang paling penting dalam psikologi pendidikan adalah guru tidak hanya sekedar memberikan pengetahuan kepada siswa. Siswa harus membangun sendiri pengetahuan di benaknya. Guru dapat memberikan kemudahan dengan memberi kesempatan siswa untuk menemukan atau menerapkan ide sendiri, dan mengajar siswa menggunakan strategi mereka untuk belajar. Guru memberikan siswa anak tangga mengarahkan siswa ke pemahaman yang lebih tinggi, dengan siswa sendiri yang harus memanjat anak tangga tersebut (Nur dalam Trianto 2007:14).

Guna mengoptimalkan kerja otak peserta didik, diperlukan pelatihan dan metode pembelajaran yang tepat (Rustan, 2017). Model pembelajaran scramble tidak telepas dari pertanyaan dan jawaban. Tanya jawab adalah bagian yang efektif dan penting dari pembelajaran disebabkan oleh : (a) memungkinkan guru untuk memeriksa pemahaman siswa tentang pelajarannya; (b) memungkinkan siswa untuk mempraktikkan dan menguasai topik yang diajarkan sebelum mereka harus pindah ke topik berikutnya; (c) memungkinkan siswa untuk mengungkapkan pemikiran dan pemahaman mereka tentang konsep yang diajarkan (Daniel dan David, 2008:67).

Selain aktivitas belajar dan motivasi, hasil belajar merupakan salah satu yang menjadi objek dalam penelitian ini. Menurut Dimyati dan Mudjiono (2006) hasil belajar merupakan hal yang dipandang dari dua sisi yaitu siswa dan guru. Dari sisi siswa, hasil belajar merupakan tingkat perkembangan mental yang lebih baik dibanding sebelum belajar. Tingkat perkembangan mental tersebut terwujud pada ranah kognitif, afektif, dan psikomotor, sedangkan dari sisi guru, hasil belajar merupakan penyelesaian bahan 
pelajaran. Setelah guru menerapkan model pembelajaran scramble diharapkan hasil belajar siswa dapat menunjukkan peningkatan sesuai dengan KKM yang ditetapkan di SDN 24 Temmalebba Kota Palopo yaitu >75.

\section{METODE}

Penelitian ini dilakukan dengan menggunakan metode deskriptif, yang mendeskripsikan motivasi dan hasil belajar siswa pada pembelajaran IPA menggunakan model pembelajaran kooperatif tipe scramble. Subjek penelitian ini adalah siswa kelas IIIb SDN 24 Temmalebba Kota Palopo. Sedangkan objek penelitian adalah motivasi dan hasil belajar siswa dalam pembelajaran IPA menggunakan model pembelajaran kooperatif tipe scramble.

Jenis penelitian ini adalah PTK dengan menggunakan desain penelitian model Kurt Lewin dilakukan dalam tiga siklus. Setiap siklus dilakukan empat pertemuan. Teknik pengumpulan data yang digunakan dalam penelitian ini yaitu observasi, wawancara, dokumentasi, dan tes. Observasi dilakukan untuk memperoleh data mengenai aktivitas siswa dalam pembelajaran. Observasi dilakukan dengan menggunakan lembar observasi motivasi belajar siswa dan aktivitas guru dalam pembelajaran. Wawancara dimaksudkan untuk memperoleh informasi dari guru dan siswa untuk mengetahui kemampuan siswa dan kemampuan guru mengondisikan kelasnya sebelum diadakan tindakan. Dokumentasi dilakukan untuk menyediakan dokumen dengan menggunakan bukti yang akurat. Dalam hal ini adalah pencarian berlangsung pada saat pembelajaran. Berupa foto siswa pada saat pembelajaran berlangsung di kelas, dan data-data yang ada di sekolah. Tes digunakan guru untuk mengukur kemampuan siswa dan disusun berdasarkan tujuan pembelajaran yang akan dicapai. Tes ini akan diberikan setiap akhir siklus dalam bentuk soal yang diberikan yaitu tes objektif.

Data yang diperoleh dalam penelitian ini dianalisis menggunakan deskriptif kuantitatif, yakni dengan teknik persentasi dan rata-rata. Data kuantitatif dianalisis menggunakan rumus yang dikemukakan oleh (1) Arikunto (2002:264) untuk mencari nilai rata-rata (2) rumus mencari persentasi nilai kemampuan siswa yang dikemukakan oleh Sudijono (2007: 81) yaitu untuk mengetahui presentasi klasikal hasil belajar dan presentasi motivasi belajar siswa.

Data kualitatif yaitu berupa informasi berbentuk kalimat yang memberi gambaran tantang ekspresi siswa. Untuk mengungkap makna dibalik data, penelitian ini menggunakan model dan analisis yang diperkenalkan Miles dan Huberman dalam Sugiyono (2011:247-253) dijelaskan analisis data kualitatif dilakukan secara interaktif serta berlangsung secara terus menerus sampai 
86 | Nur Azizah Zainuddin

tuntas data yang diperoleh dianalisis sampai jenuh menghasilkan kesimpulan selama penelitian berlangsung. Analisis data dilakukan dalam 3 tahap yaitu tahap reduksi data, tahap display data, tahap simpulan atau verifikasi.

\section{HASIL PENELITIAN}

\section{Penerapan Model Scramble Dalam Meningkatkan Motivasi Belajar Siswa}

Pengukuran motivasi belajar siswa dilakukan pada prasiklus, siklus I, siklus II, dan siklus III. Persentasi motivasi belajar siswa pada pra siklus adalah 47,86\%. Setelah diberi tindakan siklus I motivasi belajar siswa meningkat menjadi $62,83 \%$. Pada siklus II presentasi motivasi belajar siswa meningkat menjadi 68,10\%. Motivasi belajar siswa lebih meningkat lagi setelah diberi tindakan siklus III yaitu menjadi 82,35\%. Peningkatan motivasi belajar siswa dengan menggunakan model pembelajaran scramble secara jelas dapat dilihat pada diagram berikut:

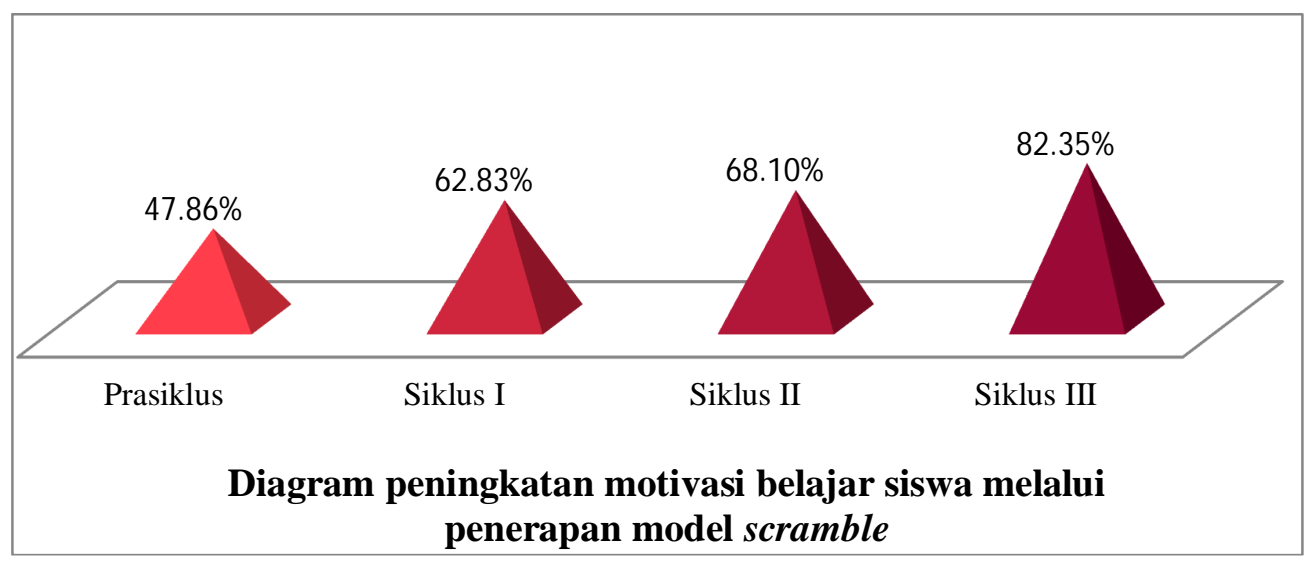

\section{Peningkatan Hasil Belajar IPA Melalui Penerapan Model Scramble}

Pengukuran hasil belajar siswa dilakukan pada prasiklus, akhir siklus I, akhir siklus II, dan akhir siklus III. Rata-rata nilai siswa sebelum menggunakan model pembelajaran scramble adalah 60 dengan ketuntasan klasikal sebesar $53,84 \%$. Rata-rata nilai siswa setelah menggunakan model pembelajaran scramble siklus I meningkat menjadi 70,1 dengan ketuntasan klasikal sebesar $61,54 \%$. Pada siklus II rata-rata nilai siswa mencapai 85,38 dengan ketuntasan klasikal 76,92\% dan lebih meningkat lagi pada siklus III 
yaitu menjadi 88,94 dengan ketuntasan klasikal 100\%. Peningkatan belajar tersebut dapat dilihat pada diagram berikut :

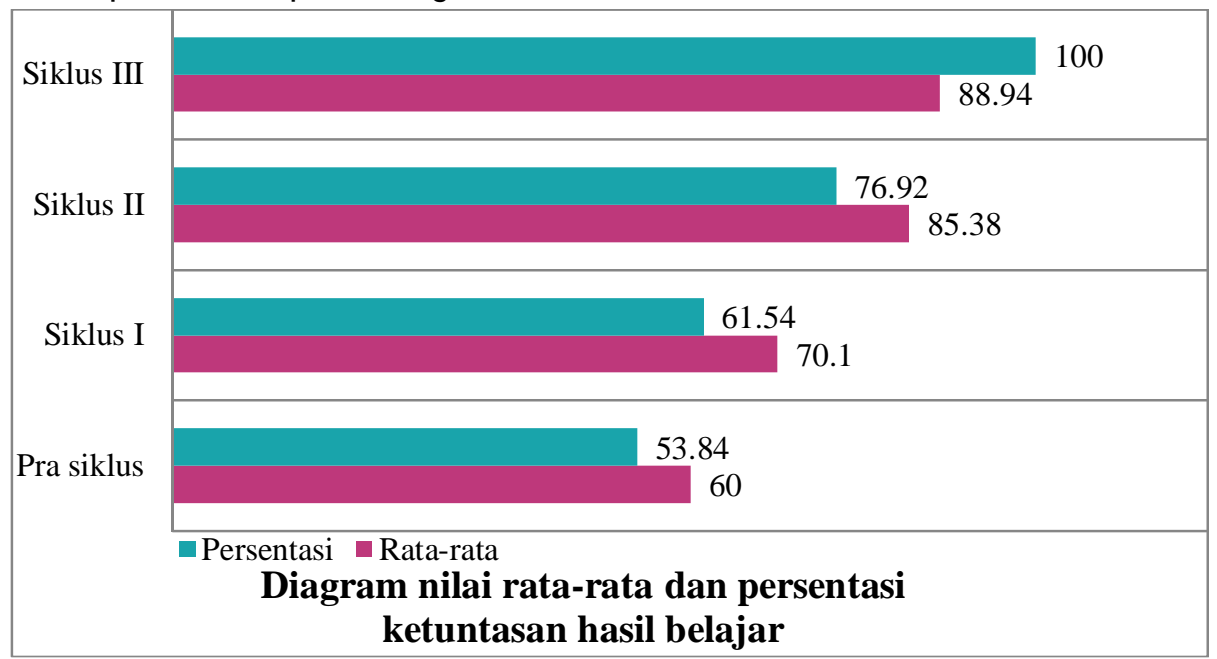

\section{PEMBAHASAN}

Penelitian tindakan kelas ini dilakukan untuk mengetahui penerapan model pembelajaran scramble dalam meningkatkan motivasi dan hasil belajar IPA pada siswa kelas IIIb di SD Negeri 24 Temmalebba Kota Palopo. Adapun persentasi motivasi belajar siswa berdasarkan hasil observasi awal yaitu 47,86\%. Pada siklus I 62,67\%, siklus II 68,94\%, dan pada tahap siklus III mencapai $78,43 \%$. Sehingga dapat dipahami bahwa motivasi belajar siswa selalu menunjukkan peningkatan yang signifikan dalam setiap siklus.

Dari hasil penelitian menunjukkan bahwa tingkat motivasi siswa meningkat. Guru memberikan penghargaan verbal terhadap siswa agar dapat meningkatkn motivasi belajar siswa. Hal yang dilakukan guru tersebut sejalan dengan teori penguatan dalam pendidikan. Teori ini dikembangkan oleh B.F Skinner dalam Danim dan Khairil (2014: 107), Beliau percaya bahwa perilaku adalah fungsi dari konsekuensinya. Siswa akan mengulangi perilaku yang diinginkan jika perilaku yang positif (konsekuensi yang menyenangkan) menyertai perilaku. Penguatan positif atau "imbalan" dapat mencakup penguatan verbal seperti "bagus", "bagus sekali", "sukses", "sukses selalu", "pertahankan prestasimu", dan sebagainya. Penguatan positif juga dapat berupa penghargaan lebih nyata seperti pemberian hadiah, sertifikat, dan sebagainya. Guru mengoptimalkan kemampuannya dalam menciptakan pembelajaran yang kondusif dan menyenangkan bagi siswa. Oleh karena itu, motivasi belajar siswa dapat menunjukkan peningkatan setiap siklus. 


\section{8 | Nur Azizah Zainuddin}

Peningkatan motivasi belajar siswa tersebut berkaitan erat dengan model pembelajaran yang diterapkan dalam pembelajaran yaitu model scramble. Miftahul huda (2015 : 306) dalam bukunya berjudul Model-model Pembelajaran dan Pengajaran, menyatakan bahwa kelebihan model pembelajaran scramble adalah (1) melatih siswa untuk berpikir cepat dan tepat (2) mendorong siswa untuk belajar mengejakan soal dengan jawaban acak, dan (3) melatih kedisiplinan siswa. Penerapan model tersebut memberikan kontribusi positif terhadap proses pembelajaran. Sehingga memudahkan guru dalam menyampaikan materi penggolongan tumbuhan berdasarkan bijinya selama penelitian ini dilaksanakan.

Menurut Lindgren dalam Suprijono (2015: 7), hasil pembelajaran meliputi kecakapan, informasi, pengertian, dan sikap. Selain nilai hasil belajar yang didapatkan siswa, mereka juga memperoleh informasi dan pengertian berupa pengetahuan. Dari pengetahuan tersebut mengubah sikap siswa sebelum dan sesudah memperoleh pengetahuan tersebut. Penelitian yang dilakukan oleh McClelland dalam Slameto (1995:181) menunjukkan bahwa motivasi belajar mempunyai kontribusi sampai $64 \%$ terhadap hasil belajar siswa. Sejalan dengan meningkatnya motivasi belajar siswa, hasil belajar IPA siswa melalui penerapan model scramble pun menunjukkan peningkatan mulai dari prasiklus, siklus I, siklus II, dan siklus III. Peningkatan tersebut dapat diketahui berdasarkan persentasi ketuntasan klasikal hasil belajar siswa, yaitu prasiklus $51,28 \%$, siklus I $61,53 \%$, siklus II 76,93\%, pada siklus III mencapai $100 \%$.

Berdasarkan nilai hasil belajar siswa yang diperoleh pada siklus III, dapat dikatakan bahwa pada saat diterapkan model pembelajaran scramble dalam pembelajaran memberikan dampak yang positif terhadap motivasi dan hasil belajar IPA siswa. Indikator keberhasilan dalam penelitian ini telah tercapai, dalam hal ini 39 siswa telah mencapai nilai $>75$, maka penelitian ini dihentikan sampai pada siklus III. Hal ini menunjukkan bahwa motivasi dan hasil belajar IPA siswa kelas IIIb SDN 24 Temmalebba Kota Palopo meningkat pada saat model pembelajaran scramble diterapkan.

\section{PENUTUP}

Berdasarkan hasil penelitian, dapat disimpulkan bahwa (1) penelitian dengan menerapkan model scramble pada pembelajaran IPA di kelas IIIb SDN 24 Temmalebba Kota Palopo dapat meningkatkan motivasi belajar siswa. Dengan diterapkannya model pembelajaran tersebut, siswa lebih memperhatikan penjelasan guru dengan baik dan lebih antusias dalam belajar. Selain bekerja sama, siswa juga dapat lebih kreatif dalam memecahkan permasalahan. Yaitu, jawaban yang diacak harus disempurnakan terlebih dahulu menjadi jawaban yang benar kemudian PiJIES: Pedagogik Journal of Islamic Elementary School 
dipasangkan dengan kartu soal yang telah disiapkan oleh guru. (2) penerapan Model pembelajaran scramble dapat meningkatkan hasil belajar IPA pada siswa kelas IIIb SDN 24 Temmalebba Kota Palopo.

Berdasarkan hasil uraian pada penelitian ini, peneliti mengemukakan beberapa saran sebagai berikut: (1) Penggunaan model dalam pembelajaran, dapat meningkatkan motivasi dan hasil belajar siswa, untuk itu dalam pembelajaran IPA sebaiknya menggunakan model yang menarik bagi siswa salah satunya adalah model pembelajaran scramble. (2) Guru diharapkan lebih memperhatikan dan mengondisikan siswa agar pembelajaran berlangsung dengan baik.

\section{DAFTAR PUSTAKA}

Arikunto, Suharsimi. 2002. Dasar-Dasar Evaluasi Pendidikan, Ed. Revisi III; Jakarta: Bumi Aksara.

Danim, Sudarwan dan Khairil. 2014. Psikologi Pendidikan (Dalam Perspektif Baru), Cet. III, Bandung : Alfabeta

Dimyati dan Mudjiono. 2006. Belajar dan Pembelajaran. Jakarta: Rineka Cipta

Huda, Miftahul. 2015. Model-model Pengajaran dan Pembelajaran, Cet.IV Yogyakarta : Pustaka Pelajar

Iryanti, Iis Listiani. 2012. Penerapan Model Pembelajaran Kooperatif Scramble Untuk Meningkatkan Hasil Belajar PadaMata Pelajaran Ilmu PengetahuanSosial.Jurnal Pendidikan.Vol.1. No.1.

Malechah, Nur. 2011. Perbandingan Hasil Belajar Siswa Dengan Menggunakan Model Pembelajaran Course Review Horey (CRH) Dan Model Pembelajaran Scramble Berbantuan LKS Pada Pokok Bahasan Bangun Datar Siswa Kelas VII Semester II SMP N 2 Sayung Demak Tahun Pelajaran 2010/2011. Semarang: Skripsi Jurusan Pendidikan Matematika Universitas PGRI Semarang.

Muijs, Daniel dan David Reynolds. 2008. Effective Teaching. Yogyakarta: Pustaka Pelajar

Rasana, I Dewa Putu Raka.2009.Laporan Sabbatical Leave Model-model Pembelajaran.Singaraja: DIPA PNBP FIP UNDIKSHA.

Rusman. 2011. Model-model Pembelajaran Mengembangkan Profesionalisme Guru. Jakarta: PT. Raja Grafindo Persada

Rustan, E. (2017). Learning Creative Writing Model Based on Neurolinguistic Programming. International Journal of Language Education and Culture Review, 3(2), 13-29. https:/ / doi.org/ 10.21009/ IJLECR.032.02

Sagala, Syaiful. 2007. Konsep dan Makna pembelajaran. Bandung : CV Alfabeta 


\section{0 | Nur Azizah Zainuddin}

Sardiman. 2003. Pengertian Motivasi. http:// eprints.uny.ac.id/ pengertian motivasi belajar.pdf/ . Diakses pada tanggal 14Februari 2018

Sekarwiyati, Pembayun. Meningkatkan Motivasi dan Prestasi Belajar IPA dengan Menggunakan Metode Pembelajaran Discovery pada Siswa Kelas V di SDN Pagak 04 Kecamatan Pagak Kabupaten Malang Tahun Pelajaran 2007/ 2008, http:// www. sarjanaku. Com / 2011/ 07/ contohproposal- ptk- penelitian- tindakan.html diakses pada 10 Oktober 2017

Slameto. 1995. Belajar dan Faktor-faktor yang Mempengaruhinya, Ed. Revisi Jakarta : PT Rineka Cipta

Sudijono, Anas. 2007. Pengantar Statistik Pendidikan, Ed. Ke-I; Jakarta: Raja Grafindo Persada

Sugiyono. 2011. Metode Penelitian Kuantitatif Kualitatif dan R\&D, Cet. XIII, Bandung : Alfabeta

Suprijono, Agus. 2012. Cooperative Learning Teori dan aplikasi PAKEM. Yogyakarta: Pustaka Pelajar.

Suprijono, Agus. 2013. Cooperative Learning. Yogyakarta: Pustaka Pelajar.

Suprijono, Agus. 2015. Cooperative Larning Teori dan Aplikasi PAIKEM, Cet. XIV, Yogyakarta : Pustaka Pelajar

Susanto, Ahmad. 2014. Teori Belajar dan Pembelajaran di Sekolah Dasar Cet.I. Jakarta : Kencana

Trianto, 2007. Model-Model Pembelajaran Inovatif Berorientasi Konstruktivistik. Jakarta: Prestasi Pustaka.

Uno, Hamzah B.. 2007. Teori Motivasi dan Pengukurannya Analisis di Bidang Pendidikan. Jakarta: Bumi Aksara.

Widayanti, Iis. 2011. Penerapan Model Pembelajaran Kooperatif Tipe Scramble Untuk Meningkatkan Hasil Belajar Siswa Pada Mata Pelajaran Teknologi Informasi Dan Komunikasi. Diakses dari http:// repository.upi.edu/ operator/ upload/pdf pada tanggal 15Februari2018 